\title{
STRUCTURE OF THE CONCEPT: INFORMATION CULTURE OF THE FUTURE TEACHER OF CHEMISTRY
}

\author{
Bohdan Ivashchenko ${ }^{1}$ \\ ${ }^{l}$ postgraduate student, Central Ukrainian State Pedagogical University, Kropyvnytskyi, Ukraine, e-mail: \\ ivashchenkobi@gmail.com,ORCID: https://orcid.org/0000-0003-4363-0726
}

\begin{abstract}
The article considers the preconditions for the emergence of the phenomenon and the concept of "information culture". The purpose of article is to identify the main components of the information culture of the individual, and to analyze their relationship. The author used the methods of logical comparison, systematization and generalization, which allowed to achieve the goal of the study and draw conclusions. The high rates of scientific and technological progress, the expansion of cognitive activity of people, the emergence of new sciences, the rapid change of not only production but also social technologies, the dynamism of modern society - all these aspects became the basis for significant growth of information resources. The factors of changing the attitude to the concept of "information culture" in chronological order are given. Distinctive and similar features in the views and attitudes to the "information culture" of scientists "East" and "West" are considered. The main approaches to the definition of "information culture" are highlighted. The views of scientists on the components of information culture are listed. The expediency and importance of using the activity approach to the formation of information culture are given. The main components of information culture of personality are singled out. A brief analysis of the interaction of each component is given.
\end{abstract}

Keywords: information competence, computer literacy, activity approach, culturological approach, professional education, information worldview, information activity.

JEL Classification: JEL I0; I20

Formulas: 0; fig.: 0; tabl.: 0; bibl.: 11

Introduction. We live in the surrounding flow of information now. It has become so much lately that our brain is not able to keep it in our operative menory for long. And indeed, the consumption of information has increased greatly compared to a person who lived 30 years ago. Although it used to be popular to read books and newspapers, scientists claim that modern people get many times more information without reading books. This is due to a change in the environment, namely the information. There are many more sources of information (especially the development of the Internet and everything related to it) and their availability to the masses. Also, new information and computer technologies are evolving every year, for example, there will soon be Starlink (Ilon Mask's global Wi-Fi), which will affect the lives of many. Even our ordinary smartphone can provide, along with the Internet, more information than in some libraries, and we just have it in our pockets. Many people think that the world is ruled by the one who has more money, but this is quite true, because the world is ruled by the one who has "information" in his hands. Through the same smartphones, many companies sell our personal data to advertising companies or pass it to special services. Now it is vital to be able to use modern sources of information, to use for their own purposes. And many, unfortunately, do not know how to look properly, even teenagers and young men, not to mention the elderly. Therefore, our study is relevant, because the development of information culture is able to solve these problems and meet the demands of society. 
Literary review. Considered the work of domestic and foreign scientists (N. I. Hendina, K. Voikhanskaya, B. Smirnova, E. Shapiro, V. M. Monakhov, A. O. Kuznetsov, S. A. Beshenkov, O. M. Saltovsky, Mark Hoffman, A. D. Hall, R. I. Fagin). Despite the considerable amount of research related to the understanding of the concept of "information culture" and its components, many issues remain open for further development.

Aims. The purpose of article is to identify the main components of the information culture of the individual, and to analyze their relationship.

Methods. The author used the methods of logical comparison, systematization and generalization, which allowed to achieve the goal of the study and draw conclusions.

Results. The high rates of scientific and technological progress, the expansion of cognitive activity of people, the emergence of new sciences, the rapid change of not only production but also social technologies, the dynamism of modern society all these aspects became the basis for significant growth of information resources. Their feature is that, unlike all other resources, over time they do not decrease, but on the contrary, they are characterized by growth and accumulation of volumes. Therefore, in the sphere of education, the issue of information overload of students and the need to find radical means to improve the efficiency and security of information in the development of educational programs in general and vocational education [3].

The term "information culture of the individual" appeared in the first half of the 1970s. The term "information culture" first appeared in the scientific literature in 1971 (G. Vorobyov, He drew attention to the generalized use of information and compliance with certain norms of information behavior, warning society that in the absence of appropriate norms information behavior will violate the modes of work in society and will create information "vacuums" and "essences", but the author did not formulate a definition of "information culture") [10].

This term began to be used by bibliographers, librarians, bibliologists. They understood "information culture" as library and bibliographic literacy - a set of knowledge, skills and abilities of the reader that provide effective information activities: based on knowledge of the range of existing information products, services and rules of library using, the ability to find in bibliographic manuals, catalogs and files documents, ability to use opportunities of interlibrary and international library subscription. Issues of information culture were covered in the articles of bibliographers K. Voikhanska and B. Smirnova ("Librarians and readers on information culture" 1974) and E. Shapiro ("About ways to reduce the uncertainty of information requests" 1975). As a result, the idea of information culture as a sphere of existence associated with the functioning of information in society and the formation of informational qualities of the individual began to be considered; as a scientific direction and sphere of activity. Library and bibliographic literacy can be formed in the process of information and bibliographic activities of students included in the educational activities [9]. 
In Western literature, the term "information culture" introduced the concepts of "information literacy" and the corresponding term "Information Literacy". The phrase "information literacy" first appeared in the press in a report born in 1974, written from the National Commission on Libraries and Informatics by Paul Zurkowski, who was the president of the Association of the Software and Information Industry. Zurkowski used this phrase to describe the "techniques and skills" mastered by information literates "to use a wide range of information tools, as well as primary sources in shaping information solutions to their problems." A significant contribution to the development of this concept was made by the American Library Association, in the interpretation of which an information-literate person can be called a person who is able to identify, place, evaluate information and use it most effectively [2]. As we can see, the level of understanding of the essence of the phenomenon of information culture in Western and Eastern science was expressed in different terms, but were introduced by people-bibliographers. In soviet literature there was more emphasis on the ability to possess information within the library, and in foreign literature such a restriction was not found, and the use of various information sources was emphasized.

Then, the concept of "information culture" in the 80-90s of the twentieth century. acquires a categorical status and is used in a broad special scientific and philosophical context, especially in the publications of A. Rakitov, E. Semenyuk. Attempts were made to draw the attention of the scientific community to the phenomenon of "information culture" as a rational and effective organization of intellectual activity of the individual, as well as to diagnose the level of formation of information culture of the individual. Introduction of new forms of information presentation (databases, e-books, e-magazines, newspapers, etc.), rapid development of computer information processing technologies, the emergence of automated libraries with electronic catalogs - all this has brought to the fore in the field of finding effective ways and means of working with information, the concepts of algorithmic culture and computer literacy.

The term "computer literacy" was introduced by Andrew R. Molnar in 1978, just a few months before the term first appeared in the headline of the New York Times. Several authors have tried to define it, but there was no consensus that all students should know about computers. Some believed that it was any knowledge and skills that the average citizen should know about computers, while others attributed the ability to program. And some courses partially included elements of programming at that time [1].

An article of 1985 published in the Journal of Higher Education defines computer literacy as "a collection of knowledge and skills that ordinary educated people need to work with computers in order to function effectively at work and in private life in society." The article also highlights several key skills that are part of this new literacy, including word processing, the ability to use spreadsheet programs, and the ability to use a computer to search and share information [4].

In our domestic scientific thought in this period includes the concept of "algorithmic culture" considered in the works of V.M. Monakhova, 
A. O. Kuznetsova. S. A. Beshenkova, O. M. Saltovsky. Algorithmic culture of students means a set of specific ability to build algorithms for computational, technological and other types of processes, programming in algorithmic languages of a particular level, knowledge of the structure and principles of microprocessor systems, their means of communication with the environment.

The term "computer literacy", borrowed from abroad, began to be used by V. Militarev, E. Smirnov, I. Yagl in publications to denote another concept "information culture". Computer literacy was understood as:

- ability to effectively use computer technology in all areas of human activity;

- ability to read, write, draw, search for information using a computer;

- use of input devices (keyboard, various sensors of temperature, pressure, air pollution, etc.) and information output (printers, displays, analog-to-digital and digital-to-analog converters),

- ability to apply microprocessor technology in various fields of science and production, knowledge of the capabilities of computers and methods of solving problems with their help.

Approaches have been developed to the formation of not only computer literacy, but computer culture, say some domestic scientists, A. Ershov and V. Monakhov in computer culture included, in addition to computer literacy, skills of competent statement of problems arising in practice, skills of their formalized description, skills of skilled use of basic types of information systems (and general-purpose application packages) to solve practical problems with their help, the ability to correctly interpret the results of solving simple practical problems using a computer and apply these results in real life [7]. Despite this, it is clear that views on computer literacy did not differ radically between "west" and "east", as it all came down to the ability to use the computer for their own purposes.

During the development of the theory of information culture, its circle of specialists began to include representatives of such sciences as semiotics, linguistics, sociology, psychology, pedagogy, culturology, aesthetics, and others.

As a result, in the 90's the point of view on the need to comprehend and generalize the accumulated knowledge of the theory of information culture in a new scientific discipline - information culturology, the theoretical foundations of which are laid in the works of Professor M. G Vokhrysheva [11]. Another factor in the new stage of understanding the concept of "information culture" was the emergence of the Internet in these years of a common information space -.

Scientists are trying to interpret the essence of information culture in the traditions and using the conceptual apparatus of "their" science, generates a number of approaches.

Within the information approach, most researchers of this phenomenon include a set of knowledge, skills and abilities to search, transmit, select, store, analyze and use information, that is everything is a part of information activities aimed at meeting the need for information. I. G. Khangeldiyeva notes that information culture is "a qualitative characteristic of human life in the sphere of receiving, transmitting, storing and using information, where the priority is universal spiritual values." 
Proponents of the information approach believe that the information culture of the individual should be studied and formed,first of all, in the context of skills and abilities to independently build professional and any other knowledge that the modern level of society needs.

The culturological approach (O. A Orlova, A. Y. Flier, S. M. Olenev, N. I. Gendina and others) is directed on knowledge of it as the subject of culture defining socially -information program and the direction of its life, being a universal characteristic of sociocultural activity of the person. From the point of view of the culturological approach, information culture forms the orientation of the individual, first of all worldviews, cultural needs and value orientations of the individual in relation to information, and also cultural immunity consisting in information selfdefense of intellect. This approach was also used by S. D. Karakozov. He argues that the information culture of the individual is an integral part of the basic culture of the individual as a systemic characteristic of man, which allows him to effectively participate in all types of work with information - obtaining, accumulating, encoding and processing of any kind of information. It includes literacy and competence in understanding the nature of information processes and relations, humanistically oriented information value-semantic sphere (aspirations, interests, worldview, value orientations), developed information reflection, also creativity in information behavior and social -information activity. Information culture is closely intertwined with many other types of cultures: economic, political, legal, moral, environmental, religious, etc., in culturological terms, and it is an integral part of them, a "crosscutting" aspect that permeates culture in total. Information culture is considered as a way of human life in the information society, as part of the process of forming the culture of mankind from the standpoint of the culturological approach. [8].

The historical approach to understanding information culture is most fully represented in the works of K. K. Colin, A. I. Rakitova, E. P. Semenyuk and others. This approach emphasizes the analysis of the genesis of information culture, reveals its specific historical and social conditionality and, as a result, attempts are made to form a historical model of information culture, which "must combine the time factor and the list of components of information culture."

The pedagogical approach to understanding is defined as a set of rules of human behavior in the information society, ways and norms of communication with artificial intelligence systems, dialogue in human-machine systems "hybrid intelligence", use of telematics, global and local information and computer networks. It includes the ability of people to realize and master the information picture of the world as a system of symbols and signs, direct and feedback information links, to navigate freely in the information society.

Psychological and pedagogical approach (E. P. Belinskaya, G. A. Bordovsky, E. N. Bondarevskaya, Y. M. Babayeva, A. G. Voiskunsky, V. V. Serikov, I. S. Yakimanskaya and others) in the formation of information culture to take into account individual and age characteristics of the individual, the degree of its information activity, computer literacy in order to ensure professional self-realization. Information culture is considered by researchers as a person's ability to participate in 
information processes, as an integral concept based on the synthesis of audiovisual, logical, conceptual and terminological, communication and network varieties of cultures, on the system of moral and ethical norms and rules.

Sociological approach: information culture is a term used to denote the achieved level of organization of information processes, the degree of satisfaction of people in information communication, the level of efficiency of creation, collection, storage, processing, transmission, presentation and use of information. consequences of decisions. According to a number of modern scientists (N. I. Kolkov, I. L. Skipor, G. A. Starodubova, A. V. Urazova and others) the concept of "information culture" includes:

- ability to use modern means of extraction, processing and systematization of knowledge;

- understanding the nature and role of information processes in nature and society;

- skills of application of the information approach in the analysis of objects and the phenomena in a society;

- ability to work with different sources of information;

- mastery of the basics of analytical and synthetic information processing and others.

According to scientists of the socio-cultural approach (M. A. Ariarsky, Y. A. Akunin, E. I. Grigoriev, I. A. Gerasimov, N. N. Yaroshenko, A. P. Markov and others) the concept of "information culture personality "consists of:

- harmonization of the spiritual world of the individual in the process of mastering socially significant information;

- in the ability to social adaptation in dynamically changing economic, political, cultural conditions;

- in the independence of interpretation of the received information;

- in developed critical thinking;

- in the choice of socio-cultural activities in the information society, as part of the formation of personal culture.

The systems approach (L. von Bertalanffy, E. G. Yudin, I. V. Blauberg, V. M. Sadovsky, A. D. Hall, R. I. Fagin, and others) reflects the general connection and mutual conditionality of phenomena and processes of the surrounding sociocultural reality, focuses on the study of phenomena as systems that have a certain structure and specific patterns of functioning.

The above approach is designed to consider relatively independent components of information culture not in isolation, but in the relationship and dynamics, which allows to identify integrative system properties and qualitative characteristics of this concept, to provide a holistic view of the phenomenon of information culture as a dialectical unity of material and spiritual culture as a manifestation of information needs of certain social groups of people, as a process of implementation of information and communication technologies that open opportunities for personal and professional development. The functional structural components of the concept of "information culture" are: basic information structures that determine the processes of interaction between the subsystems of culture; orientational information structures that characterize the relationship between culture and personality [9]. 
The activity approach to information culture developed in recent years and presented in the publications of N. R. Nurmeeva, N. A. Vodopyanova, K. R. Ovchinnikova and others, which allows to reveal and characterize its functional and substantive side in the conditions of reproduction and transformation of human existence. Within the framework of this approach, culture appears as a general form of human activity for the reproduction and renewal of social life and, at the same time, a way of organizing this activity, its products and results. In turn, information culture, as the most important component of the general culture of man and society, is considered as the total amount of all previous experience of human activity in the field of obtaining and using information, presented in a generalized form [6].

As we see, there are many approaches, but most of them are theoretical character, and to form an information culture is possible only in the activity (which is the basis of the activity approach). It is necessary to analyze the structure of information culture and identify the impact of activities on its components to verify this. Since there is no single definition of the concept of "information culture", it is logical that the views of scientists on the structure of information culture of the individual will be different.

Vokhrysheva M.G identifies the following components: information competence; communicative competence; value orientations; information worldview. Sygovtsev G. S believes that the components of information culture of the individual are: information activities; information hygiene; information worldview. And according to Drannikova G. V - this is an informational style of thinking; information activities; information worldview [5].

Discussion. Analyzing it, we can say that most scientists include in the structure of information culture of the individual information activities and information worldview. This is confirmed by the study of Khaibulaev M. H, where the results of a survey of scientists and students, which components of information culture most often identified: information activities, information worldview, communicative competence and information competence. And this is not surprising, because these components naturally follow from the essence of the phenomenon of "information culture". After all, one of the main tasks of information culture is to prepare people for life in the conditions of informatization. This preparedness is expressed in the skills and abilities that are manifested and formed just in the course of information activities, and the rational use of activities in combination with information and communication technologies forms information competence. During such practical contact with information (due to our psychology, because we have feelings and emotions) we have a reaction to the processed information, which is manifested in the formation of values and views, which is the basis of information worldview. And communicative competence is not only important for the proper using of information and communication technologies (which are necessary for information activities), but also a key element of human interaction, which is an important factor in the development of information culture of society. Such an information society in turn affects the information culture of an individual (especially the requirements for this culture), precisely because we are all social creatures. 
Therefore, the components of information culture are interconnected and mutually influence each other, not only at the level of the individual, but also society.

Conclusions. So, given that the concept of information culture is multifaceted, the definition of this concept depends on the goals and nature of the author's research. Considering the approaches, we came to the conclusion that the vector of development and formation of information culture is aimed at information activities now (the process during which a person transforms and learns about the cultural environment), that is the dominance of the activity approach. After all, the activity approach can be used in the formation of almost all components of information culture specialist psychological and pedagogical education, as information competencies are formed exclusively in the course of creativity of the students, in the process of practical classes, independent work in solving professional problems.

In the analysis, the views of scientists on the structure of information culture of the individual, it was found that can be divided into intangible (for axample, information worldview) and material components (information activities). These components are inseparable, form a whole, and affect each other.

\section{References:}

1. Etherington C. (2018), Computer literacy: what it was and eventually became [Electronic resource] / Cait Etherington. Resource access mode: https://news.elearninginside.com/computer-literacy-what-it-was-andeventually-became [in English].

2. Gendina N.I. (2007), Informacionnaya gramotnost' i informacionnaya kul'tura lichnosti: mirovye trendy $i$ rossijskij opyt [Information literacy and information culture of personality: international trends and Russian experience], Shkol'naya biblioteka, №8. [in Russian].

3. Gendina N.I. (2006), Formirovanie informacionnoj kul'tury lichnosti: Teoriya. Obosnovanie $i$ modelirovanie soderzhaniya uprazhnenij po discipline [Formation of information culture of personality: Theory. Substantiation and modeling of the content of exercises discipline], M.: Mezhregion. central'noe sotrudnichestvo, $512 \mathrm{~s}$. [in Russian].

4. Hoffman M.E. (2003), Computer literacy: Today and tomorrow / Mark Hoffman. // ReseachGate. [in English].

5. Khaibulaev M.H. (2015), Struktura i komponenty informacionnoj kul'tury shkol'nikov [Structure and components of information culture of schoolchildren], Novosti DGPU, №2. [in Russian].

6. Kiselyov G.M. (2015), Metodologicheskie podhody k formirovaniyu informacionnoj kul'tury pedagogapsihologa $v$ informacionnoj obrazovatel'noj srede [Methodological approaches to the formation of information culture of a teacher-psychologist in the information educational environment], Vestnik VEDU, №2. [in Russian].

7. Makarenko L.L. (2008), Komp'yuterna gramotnist': teoriya i praktika: monografiya [Computer literacy: Theory and practice: a monograph], Kyiv: Osvita Ukraini, 244 s. [in Ukrainian]

8. Mamontova N.I. (2010), Osnovnye podhody k ponyatiyu «informacionnaya kul'tura» [Basic approaches to the concept of "Information Culture"], Vestnik Kostromskogo gosudarstvennogo universiteta, №3. [in Russian].

9. Teplaya N.A. (2012), Sovremennye podhody $k$ opredeleniyu ponyatiya $i$ sushchnosti formirovaniya informacionnoj kul'tury [Modern approaches to defining the concept and essence of the formation of information culture], Sovremennye issledovaniya social'nyh problem, №6. [in Russian].

10. Vinaryk L.S. (2009), Informacionnaya kul'tura v sovremennom obshchestve [Information culture in modern society], Mekhanizm ekonomicheskogo regulirovaniya, №2. [in Russian].

11. Vokhrisheva M.G. (1997), Stanovlenie nauki ob informacionnoj kul'ture. Problemy informacionnoj kul'tury: Sbornik statej [Formation of the science of information culture], Problems of information culture: Collection of articles. - M.; Magnitogorsk: Magnitogorsk State Publishing House. Conservatory. E. Glinka, №6, 191 p. [in Russian]. 